\title{
Small intestine enteroscopy: a new diagnostic tool not only in HIV infection
}

\author{
Christian Traeder, Julia Breitkreutz, Keikawus Arastéh \\ From $16^{\text {th }}$ International Symposium on HIV and Emerging Infectious Diseases \\ Marseille, France. 24-26 March 2010
}

\section{Background}

Since 2007 the department of infectious diseases of the Vivantes Auguste Viktoria Klinikum Berlin, Germany has established the single balloon enteroscopy of the small intestine. To demonstrate the usefulness of this method we report a case of a 48 year old HIV positive patient.

\section{Methods}

Case report and analysis of electronic data base for results of enteroscopies since 2007.

\section{Results}

Admission with anemia and reported bloodloss, which was not seen by professional health care workers. CD4 count $70 / \mathrm{ml}$, viral load $<50$ copies, HAART since 6 month. Gastroscopy and coloscopy showed no evidence of current GI bleeding and revealed no bleeding source. Staging by CT scan (cerebral, cervical, thoracical and abdominal) showed lymphnodes smaller than $1 \mathrm{~cm}$, no suspicion for lymphoma, especially in the small intestine. Bone marrow biopsy was without pathological findings. The patient received blood transfusion, hemoglobin levels remained constant. To complete our diagnostic approach we performed a single ballon enteroscopy via oral routine. Approximatly $210 \mathrm{~cm}$ a.d. we found a semicircular ulcerating lesion followed by a circular protruding and ulcerating tumor which could not be passed. Histology showed a b-cell lymphoma (diffuse large cell, CD20 positive).

\section{Discussion}

The case report demonstrates the usefulness of the new method of single balloon enteroscopy. In our experience

\footnotetext{
* Correspondence: christian.traeder@vivantes.de

Vivantes Auguste Viktoria Hospital, Berlin, Germany
}

$10 \%$ of all enteroscopies in HIV infection discovered pathological findings with therapeutic consequences.

Published: 11 May 2010

doi:10.1186/1742-4690-7-S1-P82

Cite this article as: Traeder et al:: Small intestine enteroscopy: a new diagnostic tool not only in HIV infection. Retrovirology 2010 7(Suppl 1): P82.
Submit your next manuscript to BioMed Central and take full advantage of:

- Convenient online submission

- Thorough peer review

- No space constraints or color figure charges

- Immediate publication on acceptance

- Inclusion in PubMed, CAS, Scopus and Google Scholar

- Research which is freely available for redistribution

Submit your manuscript at www.biomedcentral.com/submit
C Biomed Central 